\title{
EFFICIENCY OF COW MECHANICAL DRIVER USING SIDE BY SIDE TYPE MILKING EQUIPMENT
}

\author{
Maris Mangalis, Juris Priekulis \\ Latvia University of Agriculture \\ maris.mangalis@inbox.lv, juris.priekulis@1lu.lv
}

\begin{abstract}
The article discusses the efficiency of the cow mechanical driver milking cows in side-by-side parlours $2 \times 10$. If the mechanical driver is not used, the animals must be driven by cow tenders - cow drivers and milkers, but it causes considerable consumption of work. The research has been carried out on the training and research farm of the Latvia University of Agriculture "Vecauce" where in 2015 the light type mechanical cow driver Cow Mover M of the company DeLaval was introduced. For this purpose the cow milking procedure was timed before using the mechanical driver as well as about after two years of its exploitation. In the research it was stated that usage of the mechanical driver increases the cow crowding in the waiting yard up to 1.41.5 animals calculating per one $\mathrm{m}^{2}$ of the yard area what is within the admissible limits. Therefore, the cow movement from the waiting yard to the milking places becomes faster increasing the productivity of milking from 79 to 82 cows per hour. Besides, the consumption of work of people engaged in milking decreases by $36 \%$. The calculations show that on the training and research farm of the Latvia University of Agriculture "Vecauce" introduction of the cow mechanical driver paid back within less than a year.
\end{abstract}

Key words: milking, cow mechanical driver, equipment exploitation parameters.

\section{Introduction}

The cow mechanical drivers were introduced in Latvia about ten years ago. They were installed mainly in larger milk farms where cows were milked in a separate parlour using the stand type milking equipment. The cow mechanical drivers were installed in the waiting yard. They were used for several purposes: to ensure the movement of cows from the waiting yard to the milking parlour this way making the work of the people engaged in cow driving easier as well as to make entering of the animals in the milking stands faster in order to increase the productivity of the milking equipment.

In 2007 on the training and research farm of the Latvia University of Agriculture "Vecauce" a new milk cow barn was built where side-by-side parlour type milking equipment with 2 x10 milking places was installed. At the beginning this equipment was used without the mechanical cow driver. Therefore, the cow tenders - cow drivers had to drive the cows to the waiting yard and then further to the milking parlour often engaging in this work also the milkers. But in 2016 the mechanical cow driver offered by the company DeLaval Cow Mover M was installed in the barn (Fig. 1).

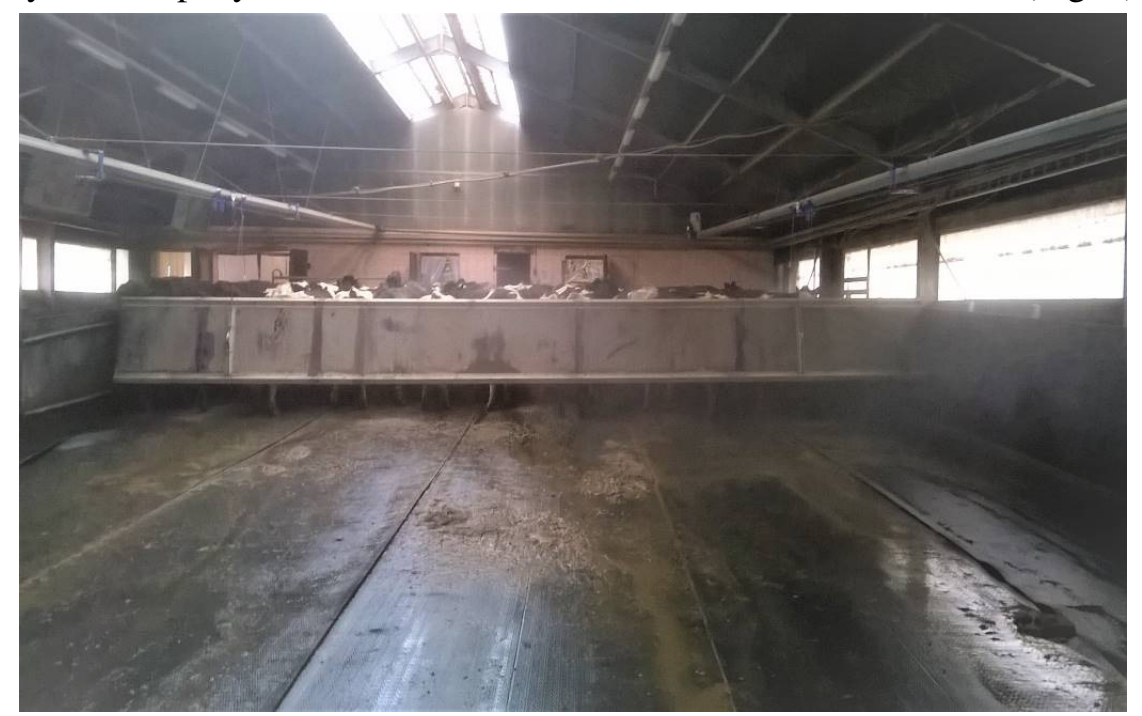

Fig. 1. Cow mechanical driver Cow Mover M of the company DeLaval introduced on the training and research farm of the Latvia University of Agriculture "Vecauce"

The main working part of this mechanical driver is a $11 \mathrm{~m}$ wide metal shield hanged in cables that can automatically move from the furthest side of the waiting yard towards the milking parlour. During 
operation this shield is at the height of the cows. Therefore, when it is moving forward, the cows are crowded and driven in the direction to the entrance into the milking parlour. If it happens that the pressure caused by the shield exceeds the beforehand adjusted value, it automatically stops. But it restarts again and continues driving, if this pressure becomes accordingly smaller. That way cow movement from the waiting yard towards the entrance into the milking parlour can be executed without direct help of people. Besides, the work of this mechanical driver was not hindered by the peculiarity of the milking equipment installed in the barn that the cows should be driven to the milking places in groups - ten cows at a time.

The timing of the cow milking procedure was done before introduction of the mechanical cow driver as well as after its introduction. Therefore, the aim of our research was to state the efficiency of the mechanical cow driver considering the productivity of the milking equipment, consumption of work of the people engaged in cow driving and the economical profitability of introduction of such driver.

\section{Materials and methods}

The research in exploitation of the introduced milking equipment on the training and research farm of the Latvia University of Agriculture "Vecauce" was carried out in two stages. The first - in 2011 and 2012 [1-3] and the second - in 2016, i.e. before introduction of the mechanical driver and about a year after its introduction. Therefore, we can consider that the cow milking regime in these periods of the research had stabilized.

The research input data are summarized in Table 1.

\section{Versions compared in the research}

Table 1

\begin{tabular}{|l|c|c|}
\hline \multicolumn{1}{|c|}{ Indicators } & $\begin{array}{c}\text { Version 1 } \\
\text { Working without the cow } \\
\text { mechanical driver }\end{array}$ & $\begin{array}{c}\text { Version 2 } \\
\text { Using the cow mechanical } \\
\text { driver }\end{array}$ \\
\hline Number of cows & 330 & 400 \\
\hline Milking equipment & $\begin{array}{c}\text { Side-by-side parlours } \\
2 \times 10\end{array}$ & $\begin{array}{c}\text { Side-by-side parlours } \\
2 \times 10\end{array}$ \\
\hline Cow mechanical driver & - & Cow Mover M \\
\hline Number of milkers & 2 & 2 \\
\hline $\begin{array}{l}\text { People engaged in driving } \\
\text { cows: } \\
\text { - drivers } \\
- \text { milkers }\end{array}$ & 1 & $1 *$ \\
\hline
\end{tabular}

*people are engaged in cow driving only when the groups of cows are changing

Milking was timed for three morning, noon and evening milking times using the installed in the barn video observation system $\mathrm{GeO}$ Vision, Multicam Survelance System, Version 8.5.9.0, Copyrigt(c) 2013.

During timing the time spent for the cows of every subgroup (including 10 animals) to enter the milking parlour, the total time of milking, as well as the consumption of labour of the people engaged in driving the cows were stated. Besides, the moment beginning with opening of the milking stand entrance gates till entrance of the last cow of the corresponding subgroup into the milking stand was considered as entrance into the milking parlour.

According to the research results the cow crowding in the waiting yard, consumption of the time for the cows to enter the milking parlour, technological productivity of the milking equipment (considering preparation and finishing work) as well as the specific consumption of labour of the people engaged in milking (man-hours $\cdot$ day $^{-1}$ ) were calculated.

To find the most important exploitation parameters the following formulas were used.

Crowding of cows in the waiting yard: 


$$
\theta=\frac{Z_{g . a}}{\Delta_{v i d} \cdot b_{l}}
$$

where $\theta$-crowding of cows in the waiting yard using the mechanical cow driver, cows $\cdot \mathrm{m}^{-2}$;

$Z_{g . a}-$ number of cows in one subgroup that are allowed into the milking stand (10 cows for the corresponding milking equipment);

$\Delta_{v i d}$ - average distance the mechanical driver moves ahead after one subgroup of cows enters the milking stand, $\mathrm{m}$;

$b_{l}$ - width of the waiting yard, $\mathrm{m}$.

Technological profitability of the milking equipment

$$
W_{t}=\frac{\sum Z_{g}}{\sum t_{s l}}
$$

where $W_{t}-$ technological profitability of the milking equipment (without including the consumption of time for preparation for work and operations finishing work, cows $\cdot \mathrm{h}^{-1}$;

$\sum Z_{g}$ - total number of cows milked during the whole period of the experiment;

$\sum t_{s l}$ - total time of milking cows during the whole period of the experiment (without including the time for preparation for work and finishing operations), $h$.

Consumption of work of people engaged in milking

$$
D=\left(\frac{Z_{g} \cdot z_{s l}}{W_{t}}+t_{p i e}\right) \cdot \frac{365}{Z_{o}},
$$

where $D$-consumption of work of people engaged in milking, man-hours $\cdot \operatorname{cow}^{-1}$ per year;

$Z_{g}$ - average number of cows milked per day;

$z_{s l}$ - number of milkers operating the milking equipment;

$Z_{o}$ - average number of cows in the herd;

$W_{t}$ - productivity of the milking equipment, cows $\cdot \mathrm{h}^{-1}$;

$t_{p i e}$ - average working time of a person engaged in cow driving, h. day ${ }^{-1}$.

Cow mechanical driver pay-back time

$$
T_{g}=\frac{K}{E_{g}}=\frac{K}{365 \cdot \frac{\left(t_{i e .1}-t_{i e .2}\right) \cdot i_{s l} \cdot Z_{g} \cdot z_{s l}}{2 \cdot 3600}+365 \cdot\left(t_{p i e .1}-t_{p i e .2}\right) \cdot i_{p i e}-I_{m}},
$$

where $T_{k}$-cow mechanical driver pay-back time, years;

$K$ - capital investments necessary for purchasing and installing of the mechanical driver, EUR;

$E_{g}$ - obtained financial economy, EUR $\cdot$ year $^{-1}$;

$t_{i e .1} ; t_{i e .2}$ - average time one cow spends for entering the milking parlour working without the mechanical driver and with the mechanical driver, $\mathrm{s}$;

$i_{s l} ; i_{p i e}$ - salary normative for a milker and the cow driver, EUR $\cdot \mathrm{h}^{-1}$;

$t_{p i e .1} ; t_{p i e .2}$ - consumption of work of a person engaged in cow driving before introduction of the mechanical driver and after it, man-hours. day $^{-1}$;

$I_{m}$ - machining costs of the mechanical driver, EUR $\cdot$ year $^{-1}$;

3600 - number to convert the time the cows are entering the milking parlour from seconds to hours;

2 - number evaluating simultaneous milking of cows in the both sides of the trench, i.e in two parallel lines.

In turn

$$
I_{m}=I_{a}+I_{k}+I_{e l}+I_{r},
$$

where $I_{a}-$ cow mechanical driver renovation costs, EUR $\cdot$ year $^{-1}$; 
$I_{k}$ - external capital costs introducing the cow mechanical driver, EUR $\cdot$ year $^{-1}$;

$I_{e l}$ - electric energy costs of the cow mechanical driver, EUR $\cdot$ year $^{-1}$;

$I_{r}$ - repair costs of the cow mechanical driver, EUR $\cdot$ year $^{-1}$.

The methodology described in literature [4] was applied to calculate these costs.

\section{Results and discussion}

The intensity of the cow movement entering the milking stand is characterised by the time taken for the subgroup of cows to enter the milking parlour. The value of this period of time calculating per one cow is shown in Figure 2.

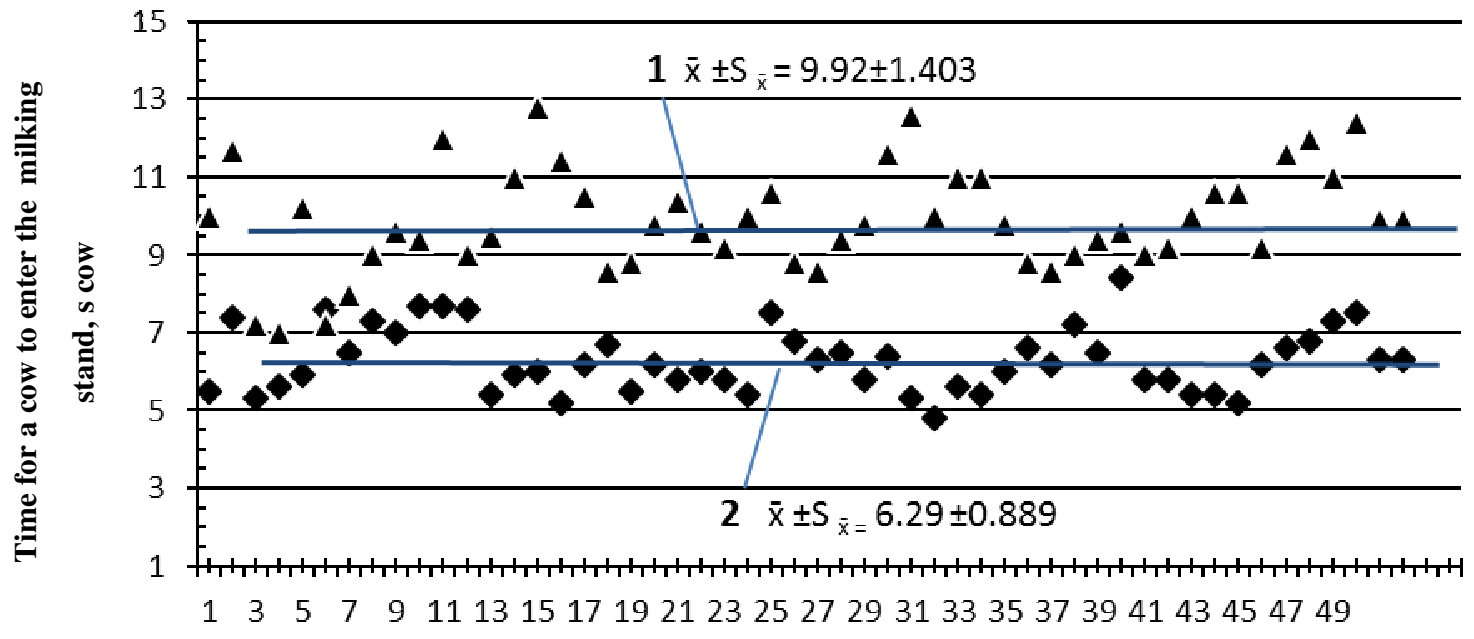

Measurement serial number

Fig. 2. Average time for one cow to enter the milking parlour: 1 - before introduction of the cow mechanical driver; 2 - after introduction of the cow mechanical driver

If the cows are driven for milking by a person (cow driver), the average time for one cow to enter the milking stand is $9.9 \mathrm{~s}$, but if the cow mechanical driver is used, this time reduces by $33 \%$, i.e. up to 6.3 seconds calculating per one animal. So, usage of the cow mechanical driver essentially influences the procedure of cow milking by hastening the movement of cows to the milking places. Besides, the intensity of the cow movement does not depend on the number of cows in the waiting yard as the cow mechanical driver not only crowds the cows in the waiting yard, but also moves them gradually towards the entrance to the milking parlour.

If, in turn, the cow mechanical driver is not used, the cows can scatter along the whole waiting yard that especially hinders the movement of cows to the parlour at the end of milking. It is proved also by our research, as Figure 2 shows that the average consumption of time for the cows to enter the milking places gradually increases. If at the beginning of milking the cows of the corresponding group it was $9.2 \mathrm{~s}$, then at the end of milking it was already10.7 s. Still, it should be mentioned that the intensity of the cow movement of separate subgroups can vary by $30-40 \%$, as it depends on the particular situation.

Our previous research $[1 ; 3]$ shows that the intensity of the cow movement moving from the waiting yard to the milking parlour to a great extent depends on crowding of cows in the waiting yard and depending on the peculiarities of the used cow mechanical driver it can reach $1.1-1.2 \mathrm{~m}^{2} \cdot \operatorname{cow}^{-1}$. But in this case crowding of cows, according to the research results, was $1.4-1.5 \mathrm{~m}^{2} \cdot \mathrm{cow}^{-1}$. Therefore, it approximately corresponds to the existing recommendations [5] indicating that the area of the waiting yard calculating per one cow should be not less than $1.5-1.6 \mathrm{~m}^{2}$.

The economic efficiency of the cow mechanical driver is related also with reduction of the labour force moving cows in the waiting yard as well as with saving of the milkers' working time due to the fact that the cows enter the milking places faster. Before introduction of the cow mechanical driver one person was needed for driving cows and this person was busy during the whole time of milking. In turn, after introduction of the cow mechanical driver engagement of a person was necessary mainly in 
the moment when the cow mechanical driver was switched on and off when the groups of cows are changing, i.e. $40 \mathrm{~min} \cdot \mathrm{day}^{-1}$.

According to the data obtained from the timing it was stated that before introduction of the cow mechanical driver the productivity of the milking equipment was $79 \mathrm{cows} \cdot \mathrm{h}^{-1}$, but after its introduction -82 cows $\cdot \mathrm{h}^{-1}$.

Calculating the consumption of time of the workers it was considered that in the barn there were on average 400 milk cows and they are divided in three groups. One group consists of highly productive cows and they are milked three times per day, but in the two other groups there are average productivity cows that are milked two times per day. So, during one day on average 930 cows are milked.

Knowing that the costs of purchasing and installing the cow mechanical driver are 10000 EUR, the total electrodrive power is $0.3 \mathrm{~kW}$, the normative service time is 10 years. Considering also the salaries of the workers on the farm it can be calculated that the pay-back time of the cow mechanical driver is 0.7 years.

The summary of the research results is given in Table 2 .

Table 2

Research results

\begin{tabular}{|c|c|c|}
\hline Indicators & $\begin{array}{c}\text { Version 1 } \\
\text { Working without the cow } \\
\text { mechanical driver }\end{array}$ & $\begin{array}{c}\text { Version 2 } \\
\text { Using the cow mechanical } \\
\text { driver }\end{array}$ \\
\hline $\begin{array}{c}\text { Average time of cows entering the } \\
\text { milking equipment, } \text { scow }^{-1}\end{array}$ & 9.9 & 6.3 \\
\hline $\begin{array}{c}\text { Technological efficiency of the } \\
\text { milking equipment, cows } \mathrm{h}^{-1}\end{array}$ & 79 & 82 \\
\hline $\begin{array}{c}\text { Consumption of work of people } \\
\text { engaged in milking, man-hours· } \text { cow }^{-1} \\
\text { per year }\end{array}$ & 33.2 & 21.3 \\
\hline $\begin{array}{c}\text { Pay-back time of the cow mechanical } \\
\text { driver, years }\end{array}$ & - & 0.7 \\
\hline
\end{tabular}

As the table shows, introduction of the cow mechanical driver increases the productivity of the milking equipment by 3 cows per hour and reduces the consumption of work of people engaged in milking by 11.9 man-hours per cow per year or $36 \%$.

\section{Conclusions}

1. If the milking equipment side-by-side parlour $2 \times 10$ is supplemented by the company DeLaval light type cow mechanical driver Cow Mover M, the time for movement of cows from the waiting yard to the milking places reduces in average by $3.3 \mathrm{~s}$ calculating per one cow that increases the productivity of the milking equipment from 79 to $82 \mathrm{cows} \cdot \mathrm{h}^{-1}$.

2. Usage of the cow mechanical driver reduced the consumption of work of the people engaged in milking from 33.2 to 21.3 man-hours $\cdot$ cow $^{-1}$ per year.

3. Introduction of the cow mechanical driver pays back in 0.7 years.

\section{References}

1. Mangalis M., Jaundžeikars D., Priekulis J. Cow Traffic Dynamics Using Mechanical Movers. Proceedings of 13th International Scientific Conference "Engineering for Rural Development". Volume 13. May 29-30, 2014, Jelgava, Latvia, pp. 59-63.

2. Приекулис Ю., Мангалис М. Исследования выгодности применения механических подгонщиков при доении коров (Research in Profitability of Usage of Mechanikal Drivers in Milking Cows). Проблемы интенсификации животноводства с учётом пространственной инфраструктуры и охраны окружающей среды. Монография под научной редакцией проф. В Романюка. Институт технологических и естественных наук: Фаленты-Варшава, 2013. 208.-211.c. (In Russian). 
3. Mangalis M., Jaundžeikars Dz. and Priekulis J. Cow crowding in waiting yard using mechanical drivers and its influence on productivity of rotary type milking equipment. / Agronomy Research. Volume 13. Number 1. Saku :Rebellis, 2015, pp. 237-244.

4. Priekulis J., Strautnieks N. Lauksaimniecības darbu mehanizācijas ekonomiskais vērtējums Jelgava: LLU, 2000, 29 lpp. (Economic Evaluation of Mechanisation of Agricultural Work). Jelgava: Latvia University of Agriculture, 2000. 29 pp. (In Latvian).

5. Mūsdienīga slaucamo govju ferma: tehnolog̣ija, tehnika, apkalpošana./ J.Priekuḷa red. (Modern Milk Farm; Technology, Servicing). Jelgava: Latvia University of Agriculture, 2012, 240 lpp. (In Latvian). 